\title{
Initial Study of Factors on Green Supply Chain Management, Green Supplier Strategy and Work System Performance
}

\author{
N. Mohamed ${ }^{1,3}$, W.H.W. Mahmood ${ }^{2}$, M.R. Muhamad ${ }^{1}$, M.Z. Yusup ${ }^{3}$ \\ ${ }^{1}$ Faculty of Manufacturing Engineering, \\ Universiti Teknikal Malaysia Melaka, Hang Tuah Jaya, 76100 Durian Tunggal, Melaka, MALAYSIA \\ ${ }^{2}$ Faculty of Mechanical and Manufacturing Engineering Technology, \\ Universiti Teknikal Malaysia Melaka, Hang Tuah Jaya, 76100 Durian Tunggal, Melaka, MALAYSIA \\ ${ }^{3}$ Department of Mould, Kolej Kemahiran Tinggi MARA Balik Pulau, Genting, \\ 11000 Balik Pulau, Pulau Pinang, MALAYSIA \\ *Corresponding Author
}

DOI: https://doi.org/10.30880/ijie.2020.12.05.021

Received 30 January 2020; Accepted 15 June 2020; Available online 30 June 2020

\begin{abstract}
In implementing green supply chain initiatives, this paper aims to explore the level of green supplier, manufacturing efficiency, environmental behaviour and company activities. In addition, the relationship between environmental practices and consumer behaviours in manufacturing was also examined. Towards this, the data was collected among Malaysian manufacturing firms using questionnaire-based survey. From the results, it is showing that the manufacturing performance through the implementation of green supply chain management has a positive relationship to environmental action and customer activities.
\end{abstract}

Keywords: Green Supplier, Manufacturing Performance, Green Supply Chain

\section{Introduction}

The rapid growth of manufacturing industry has urged manufacturers to have a flexible supply chain management (SCM) system that able to integrate all the elements involved. By focusing on the environmental aspects, Green Supply Chain Management (GSCM) was introduced with the aim of bringing environmental aspects into Supply Chain Management (SCM), starting with product design and advancing through the procurement and selection of products, manufacturing processes, final product delivery and end-of - life management [1]. These evidently produce a positive impact on social, economic and environmental goals [2]. Recent studies had showed that the implementation of green aspects (green design, green manufacturing and green logistic) in SCM can facilitate the reduction of energy consumption, reuse of material, and the redefinition of operation and production processes [3],[4].

As suggested by Li and Huang [5], the performance of GSCM can be measured through the focus on environment, economy, and competency. Based on review, there are eight indicators can be used to measure the implementation performance of GSCM as tabulated in Table 1. All these indicators are useful in order to explore how Green Supplier affecting the aspect of environment, practices, achievement and performance of manufacturers in implementing GSCM. In green element, sustainable is the ability of earth's various systems including human cultural systems and economies to survive and adapt to changing environmental conditions [6]. 
Table 1 - Indicators of Green Supplier

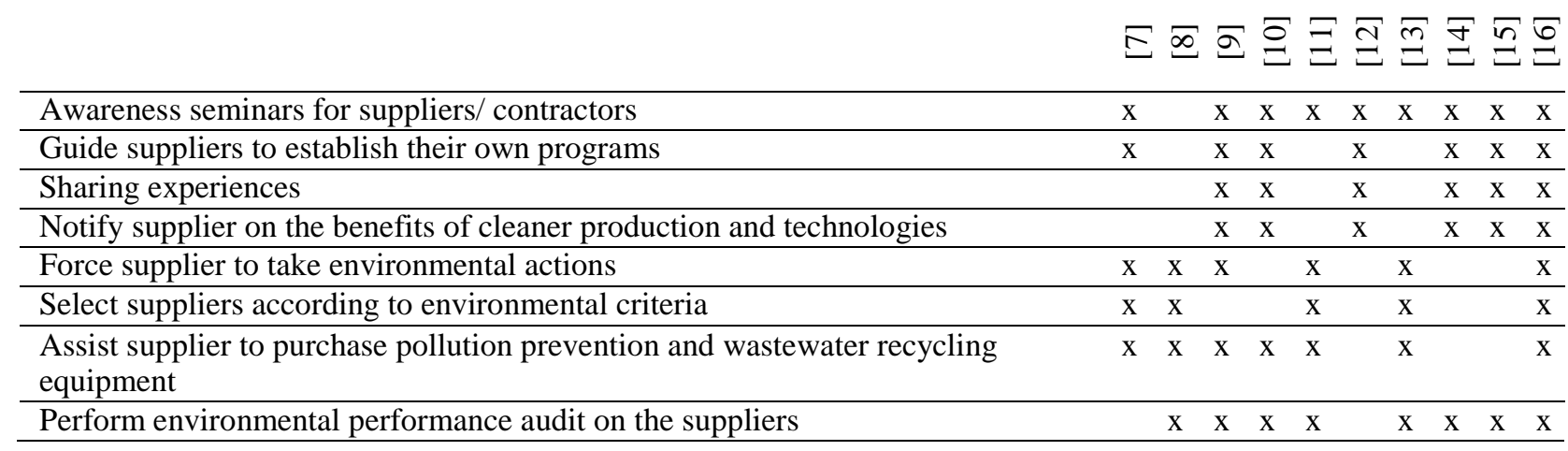

Notes: Author(s) : [9] Jabbour and Jabbour (2009); [10] Dubois and Pedersen (2002); [11] Bennett and Klug [2012]; [12] Simpson and Power (2005); [13] Sahu et al. (2014), [8] Lee (2008); [14] Genovese (2010); [15] Carr (2008); [16] Hwang and Min (2013); [17] Marksberry (2012)

This paper was structured according to the follow. Section 2 explains the study methodology; section 3 addresses the process analysis in conducting the supplier activities and the conclusion in section 4 . At the end of the paper, some suggestions for future research conclude as well.

\section{Research Methodology}

The study started by identifying the relevant information importance of the study from the existing literature review. The systematic search for relevant information then served as a scientific approach in formulating the steps taken in the review process to ensure that in a controlled situation more rigorous information about the focus area can be done. In this paper the method of research was divided into two main parts as shown in Figure 1.

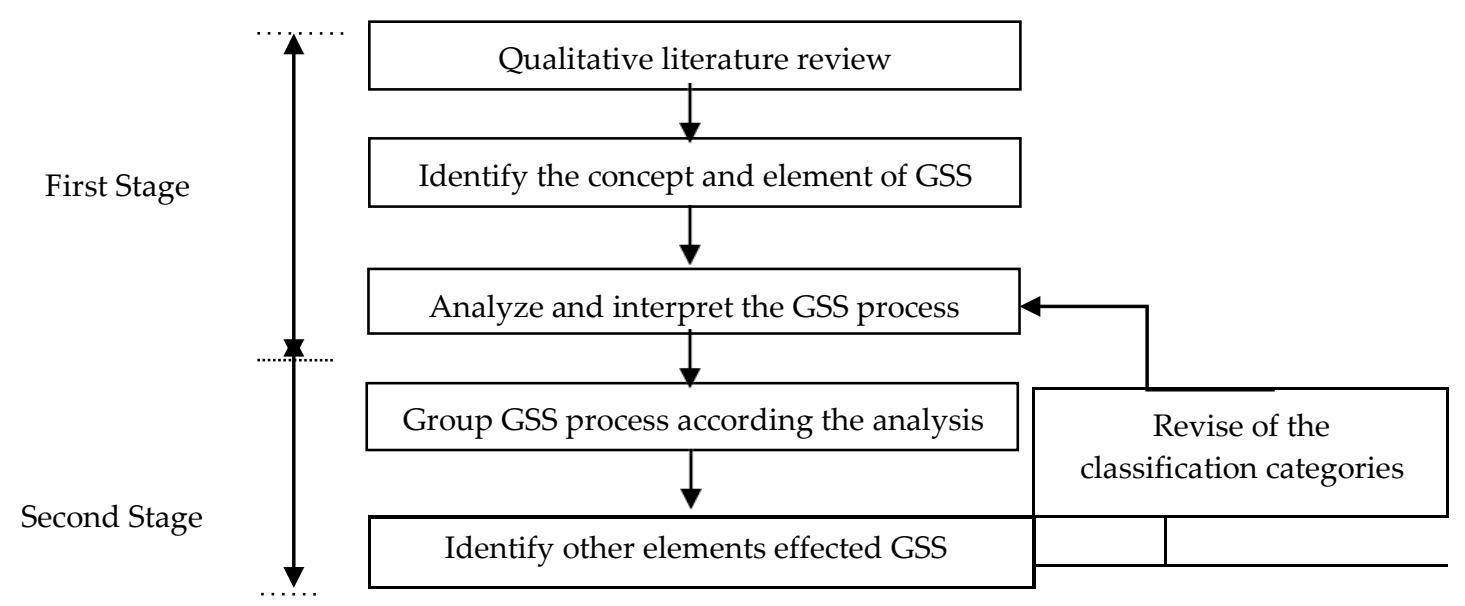

Fig. 1 - Research Method

The first stage of literature focused on the concepts and elements in Green Supplier Strategy (GSS). GSS is a criterion needs by supplier in GSCM. Groundwork of reviewing process done on literature initiatives in several focus areas to make sure it was covers in various industries. The reviewing process covers such as analytical methods, framework, findings, factors, and limitation. Next, this information was interpreted and used to identify the keys area in the interaction process of GSS.

In the second stage, the main criteria were then identified and extracted into several grouped by using factor analysis. The factor analysis was executed based on principal components analysis with the Varimax rotation at eigenvalues of discontinuity greater than 1 . The Varimax rotation methods were chosen because it can reduce the number of complex variables and improve yield expectations. Next, mean scores are used to identify the significance elements that encourage to the success of GSCM implementation. As a result, all the criteria were extracted into four group, namely Strategic Environment Process (SEP), Work Responsiveness Practices (WRP), Manufacturing System Achievement (MSA) and Work System Performance (WSP). 


\section{Result and Discussion}

In this study, analysis on the implementation of GSCM is based on four group of practices, namely Work Responsiveness Practice (WRP), Strategic Environment Practices (SEP) of GSCM, Manufacturing System Achievement (MSA) and Green Supplier Strategy (GSS). Studies by Rao [17] and [18] showed that the general overview of the GSCM implementation can be measured through any of three of these categories (WRP, SEP, MSA OR GSS). Initially, there are 13 elements extracted into WRP, followed by 21 elements in SEP, 16 elements in MSA and 8 elements in GSS. Therefore, supplier evaluation, which is an important phase in supply management, depends on assessing a wide range of quantitative and qualitative factors [19].

\subsection{Green Supplier Strategy}

Participation of suppliers in providing direct inputs to manufacturing companies has stepped up in recent years [7]. Manufacturers have increasingly seen suppliers supporting processes for improving customer quality (continuous improvement), working together in customer product development activities (early involvement of suppliers) and production inside customer production units (modular consortium). As in Table 2, Green Supplier Strategy consists of two factors. In first group, four GSS indicators (GSS 3, GSS 7, GSS 2 and GSS4) are group together with the factor loading ranging from 0.657 to 0.862 , at highest variance with eigenvalues 3.967 , and the cumulative percentage of the variance of 49.589. From the observation, supplier needs training and guiding from the manufacturer in the requirement needs in GSCM.

For the awareness, four GSS indicators (GSS 8, GSS 6, GSS 5 and GSS 1) were extracted into one factor with the factor loading ranging from 0.630 to 0.894 , eigenvalues 1.319 and cumulative percentage of variance of 66.071. The criteria included holding awareness seminars for suppliers/contractors, guiding suppliers to establish their own environmental programs, bringing together suppliers in the same industry to share their knowledge, experience and problems, and notify suppliers about the benefits of cleaner production and technologies.

Table 2 - Factor Analysis of Green Supplier Strategy

\begin{tabular}{|c|c|c|c|c|c|}
\hline Factor & Greening the Supplier & Communalities & $\begin{array}{c}\text { Factor } \\
\text { Loading }\end{array}$ & $\begin{array}{l}\text { Eigen } \\
\text { Value }\end{array}$ & $\underset{\%}{\text { Cumulative }}$ \\
\hline \multirow{4}{*}{ 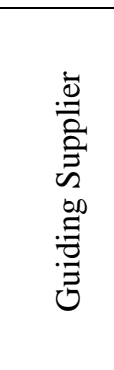 } & $\begin{array}{l}\text { Bringing together suppliers in the same industry } \\
\text { to share their know how and problems (GSS } 3 \text { ) }\end{array}$ & 0.755 & 0.862 & 3.967 & 49.589 \\
\hline & $\begin{array}{l}\text { Arranging for funds to help suppliers to purchase } \\
\text { equipment for pollution prevention, waste water } \\
\text { recycling, etc.(GSS 7) }\end{array}$ & 0.712 & 0.829 & & \\
\hline & $\begin{array}{l}\text { Guiding suppliers to establish their own } \\
\text { environmental programs (GSS 2) }\end{array}$ & 0.672 & 0.762 & & \\
\hline & $\begin{array}{l}\text { Informing suppliers about the benefits of cleaner } \\
\text { production and technologies (GSS 4) }\end{array}$ & 0.499 & 0.657 & & \\
\hline \multirow{4}{*}{ 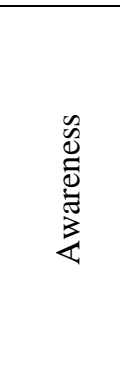 } & $\begin{array}{l}\text { Sending in-house Manufacturers auditors to } \\
\text { appraise environmental performance of suppliers } \\
\text { (GSS 8) }\end{array}$ & 0.815 & 0.894 & 1.319 & 66.071 \\
\hline & $\begin{array}{l}\text { Choice of suppliers by environment Criteria } \\
\text { (GSS 6) }\end{array}$ & 0.643 & 0.795 & & \\
\hline & $\begin{array}{l}\text { Urging/pressuring suppliers to take environmental } \\
\text { action (GSS 5) }\end{array}$ & 0.614 & 0.709 & & \\
\hline & $\begin{array}{lll}\text { Holding } \quad \text { awareness } & \text { seminars } & \text { for } \\
\text { suppliers/contractors (GSS 1) } & & \end{array}$ & 0.575 & 0.630 & & \\
\hline
\end{tabular}

\subsection{Work System Performance}

Performance measurement is an important management mechanism and is highly effective in controlling and ensuring organizational performance in line with the objectives set [20]. It aims to create relevant information in order to strengthen the decision-making, overall performance and accountability [21]. Shaw et. al, [22] also found that it is suitable for evaluating the effectiveness of specific activities.

The total variance for these factors is $58.067 \%$. As summarized in Table 3 , all the items were extracted in one group at factor loading between 0.698 to 0.831 , with the Cronbach's alpha value of 0.834 . All indicators in WSP are closely related to performance of the manufacturing performance. Based on this similarity, it is reasonable to justify this factor known as Work System Performance (WSP). 
Table 3 - Factor Analysis of Work System Performance

\begin{tabular}{|c|c|c|c|c|c|}
\hline Factor & $\begin{array}{c}\text { Performance of } \\
\text { Manufacturing } \\
\text { System }\end{array}$ & Communalities & $\begin{array}{c}\text { Factor } \\
\text { Loading }\end{array}$ & Eigen Value & $\underset{\%}{\text { Cumulative }}$ \\
\hline \multirow{6}{*}{$\begin{array}{l}\text { Work System } \\
\text { Performance } \\
\text { (WSP) }\end{array}$} & WSP 2 & 0.691 & 0.831 & \multirow[t]{6}{*}{3.484} & \multirow[t]{6}{*}{58.067} \\
\hline & WSP 1 & 0.625 & 0.791 & & \\
\hline & WSP 5 & 0.615 & 0.784 & & \\
\hline & WSP 3 & 0.536 & 0.732 & & \\
\hline & WSP 4 & 0.535 & 0.731 & & \\
\hline & WSP 6 & 0.482 & 0.698 & & \\
\hline
\end{tabular}

\subsection{Strategic Environment Practices}

The use of machinery or equipment, energy supply of electricity, water, and natural resources always considered in GSCM activities [23]. Qinghua et al., [24] found that these criteria are no limitations, however includes all activity in the supply chain management such as logistic, capacity, process flow and equipment, and other locations.

As observed from the factor analysis, twelve SEP indicators were constructed into three groups of factors, and loaded independently to each factor structured at high loading value ranging from 0.596 to 0.896 (see Table 4). In the first factor group, five SEP indicators (SEP 15, SEP 13, SEP14, SEP16 and SEP 19) are group with the factor loading ranging from 0.775 to 0.861 , at the highest variance with eigenvalues 3.516 , and the cumulative percentage of the variance of $27.046 \%$.

Table 4 - Factor Analysis of Strategic Environment Practices

\begin{tabular}{|c|c|c|c|c|c|}
\hline Factor & Environmental Actions & Communalities & $\begin{array}{c}\text { Factor } \\
\text { Loading }\end{array}$ & $\begin{array}{c}\text { Eigen } \\
\text { Values }\end{array}$ & $\underset{\%}{\text { Cumulative }}$ \\
\hline \multirow{5}{*}{ 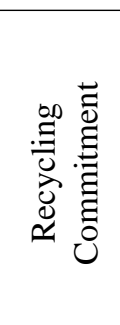 } & $\begin{array}{l}\text { Assists suppliers to establish their own EMS (SEP } \\
15 \text { ) }\end{array}$ & 0.777 & 0.861 & \multirow[t]{5}{*}{3.516} & \multirow[t]{5}{*}{27.046} \\
\hline & Use of waste of other companies (SEP 13) & 0.742 & 0.853 & & \\
\hline & Use of alternative sources of energy (SEP 14) & 0.799 & 0.851 & & \\
\hline & $\begin{array}{l}\text { Recovery of the Manufacturers end-of-life } \\
\text { products (SEP 16) }\end{array}$ & 0.693 & 0.784 & & \\
\hline & Taking back packaging (SEP 19) & 0.675 & 0.775 & & \\
\hline \multirow{4}{*}{ 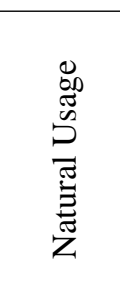 } & $\begin{array}{l}\text { Optimization of processes to reduce solid wastes } \\
\text { (SEP 7) }\end{array}$ & 0.813 & 0.896 & \multirow[t]{4}{*}{2.748} & \multirow[t]{4}{*}{48.181} \\
\hline & Design considerations (SEP 6) & 0.529 & 0.700 & & \\
\hline & $\begin{array}{l}\text { Use of cleaner technology processes to make } \\
\text { savings (energy, water, wastes) (SEP 11) }\end{array}$ & 0.588 & 0.627 & & \\
\hline & $\begin{array}{l}\text { Optimization of processes to reduce air emissions } \\
\text { (SEP 9) }\end{array}$ & 0.508 & 0.596 & & \\
\hline \multirow{3}{*}{ 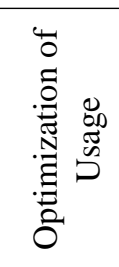 } & $\begin{array}{l}\text { Substitution of environmental questionable } \\
\text { materials (SEP 2) }\end{array}$ & 0.820 & 0.893 & \multirow{3}{*}{2.511} & \multirow{3}{*}{67.497} \\
\hline & Environment-friendly raw materials (SEP 1) & 0.723 & 0.777 & & \\
\hline & $\begin{array}{l}\text { Choice of suppliers by environmental criteria (SEP } \\
\text { 3) }\end{array}$ & 0.671 & 0.734 & & \\
\hline
\end{tabular}

\subsection{Manufacturing System Achievement}

The manufacturers that adopt GSCM practices will have better business and competitive performance, and are able to positively influence a Manufacturers' environmental performance, as well as support its competitive strategies [25]. As in Table 5, ten components were extracted into two groups. In the first group, there are four indicators (MSA 1, MSA 2, MSA 3 and MSA 5) with factor loading from 0.718 to 0.901 and eigenvalues 3.532. The first group was named as profits because the elements directly involved in profits gain by Manufacturers. The second group that involve six components (MSA 13, MSA 16, MSA 4, MSA 14 and MSA 9) with factor loading from 0.586 to 0.746 with eigenvalues 3.166. The second group names as reputation as it involves the names of the Manufacturers. 
Table 5 - Factor Analysis of Manufacturing System Achievement

\begin{tabular}{|c|c|c|c|c|c|}
\hline Factor & Benefits of GSCM & Communalities & $\begin{array}{l}\text { Factor } \\
\text { Loading }\end{array}$ & $\begin{array}{l}\text { Eigen } \\
\text { Value }\end{array}$ & $\underset{\%}{\text { Cumulative }}$ \\
\hline \multirow{4}{*}{ 象 } & Increased efficiency (MSA 1) & 0.841 & 0.901 & \multirow[t]{4}{*}{3.532} & \multirow[t]{4}{*}{35.320} \\
\hline & Quality improvement (MSA 2) & 0.862 & 0.890 & & \\
\hline & Productivity improvement (MSA 3) & 0.841 & 0.855 & & \\
\hline & Cost saving (MSA 5) & 0.597 & 0.718 & & \\
\hline \multirow{6}{*}{ 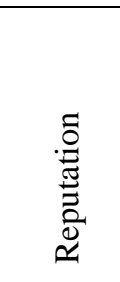 } & Social commitment (MSA 13) & 0.556 & 0.746 & \multirow[t]{6}{*}{3.166} & \multirow[t]{6}{*}{66.979} \\
\hline & Improved corporate image (MSA 6) & 0.755 & 0.741 & & \\
\hline & Preserve environment (MSA 16) & 0.578 & 0.726 & & \\
\hline & New market opportunities (MSA 4) & 0.729 & 0.707 & & \\
\hline & Sales (MSA 14) & 0.472 & 0.632 & & \\
\hline & Recycling (MSA 9) & 0.465 & 0.586 & & \\
\hline
\end{tabular}

\subsection{Work Responsive Practices}

The execution of GSCM drives the level of responsiveness in terms of employee commitment and excellence management system (training, management complaint, supplier management, non-conformity issues and etc.). Although there have several discussions on the successful factors can provide confirmation of the implementation of GSCM, but the methods and techniques are subject to the cost involve and the execution time.

As summarized in Table 6, the indicators of WRP 8, WRP 9, WRP 5, WRP 11, WRP 13 and WRP 12 are extracted below the first factor at loading value in between 0.514 to 0.785 . This factor has the highest variation with the eigenvalues of 6.288 and the cumulative variation of $48.368 \%$. Meanwhile, four indicators, i.e., WRP1, WRP 4 , WRP 2 and WRP 10 have the loading factor ranging from 0.536 to 0.804 are group into the second group. The third group contains three indicators which is WRP3, WRP 6 and WRP 7 have the loading factor ranging from 0.713 to 0.867.

Table 6 - Factor Analysis of Work Responsive Practices

\begin{tabular}{|c|c|c|c|c|c|}
\hline Factor & Quality and Customer Related & Communalities & $\begin{array}{c}\text { Factor } \\
\text { Loading }\end{array}$ & $\begin{array}{l}\text { Eigen- } \\
\text { Values }\end{array}$ & $\begin{array}{c}\text { Cumulative } \\
\%\end{array}$ \\
\hline \multirow{6}{*}{ 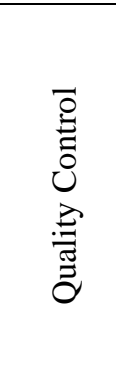 } & Use of statistical process control (SPC) (WRP 8) & 0.658 & 0.785 & \multirow[t]{6}{*}{6.288} & \multirow[t]{6}{*}{48.368} \\
\hline & $\begin{array}{l}\text { Identification of courses for non-conformity } \\
\text { (WRP 9) }\end{array}$ & 0.768 & 0.764 & & \\
\hline & $\begin{array}{l}\text { Ensure training needs are identified and records } \\
\text { of who has been trained in which topics (WRP 5) }\end{array}$ & 0.672 & 0.760 & & \\
\hline & $\begin{array}{l}\text { Employee training / employee involvement } \\
\text { (WRP 11) }\end{array}$ & 0.769 & 0.735 & & \\
\hline & Top management commitment (WRP 13) & 0.516 & 0.550 & & \\
\hline & Benchmarking (WRP 12) & 0.482 & 0.514 & & \\
\hline \multirow{4}{*}{ 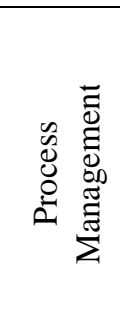 } & $\begin{array}{l}\text { Identification of customer needs/customer focus } \\
\text { (WRP 1) }\end{array}$ & 0.679 & 0.804 & \multirow[t]{4}{*}{1.368} & \multirow[t]{4}{*}{58.891} \\
\hline & $\begin{array}{l}\text { Ensure identity of preferred suppliers and a } \\
\text { system for advising them of what is expected to } \\
\text { be supplied (WRP 4) }\end{array}$ & 0.708 & 0.746 & & \\
\hline & $\begin{array}{l}\text { (Re) Defining production/operations procedures } \\
\text { to ensure greater efficiency (WRP 2) }\end{array}$ & 0.619 & 0.694 & & \\
\hline & Ensure workers commitment (WRP 10) & 0.604 & 0.536 & & \\
\hline \multirow{3}{*}{ 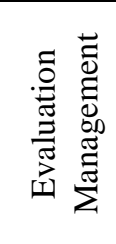 } & $\begin{array}{l}\text { Ensuring that staff are issued correct versions of } \\
\text { documentation needed to perform task (WRP 3) }\end{array}$ & 0.824 & 0.867 & \multirow[t]{3}{*}{1.119} & \multirow[t]{3}{*}{67.497} \\
\hline & $\begin{array}{llll}\begin{array}{l}\text { Ensure customer } \\
\text { addressed (WRP 6) }\end{array} & \text { complaints are properly } \\
\end{array}$ & 0.797 & 0.818 & & \\
\hline & $\begin{array}{l}\text { Ensure minimization and commitment to remove } \\
\text { non-conformities (WRP 7) }\end{array}$ & 0.679 & 0.713 & & \\
\hline
\end{tabular}




\section{Conclusion}

Malaysian manufacturers' implementation of GSCM is more focused on the activities that related to the natural source uses. Based on the results, GSS levels are primarily influenced by GSCM 's level practices in manufacturing operations. Three variables, namely SEP, WRP and MBA, significantly contributed to the improvement of the WSP, the establishment of the Green Supplier Model. These findings can provide basic information in establishing the strategy and the actions needed to achieve high levels of green practices in the manufacturing firm.

\section{Acknowledgement}

This research was co-funded by Universiti Teknikal Malaysia Melaka (UTeM) under the FRGS Grant (FRGS/1/2016/TK03/FTK-AMC/F00324) and MyPhD Grant of Ministry of Education.

\section{References}

[1] Malviya, R.K. \& Kant,R. (2014) "Identifying Critical Success Factors for Green Supply Chain Management Implementation Using Fuzzy DEMATEL Method," pp. 214-218.

[2] Zhu,W. \& He, Y.(2017)“Green product design in supply chains under competition," European Journal of Operational Research, vol. 258, no. 1, pp. 165-180.

[3] Li, Y. \& Huang, J. (2017) "The moderating role of relational bonding in green supply chain practices and performance," Journal of Purchasing and Supply Management, vol. 23, no. 4, pp. 290-299.

[4] Agrahari,P. Ravi, P. \& Sheffield,S. (2015) "Review of Green Supply Chain Processes," IFAC-PapersOnLine, vol. 48, no. 3, pp. 374-381.

[5] Beamon,B.M. (1999) "Designing the green supply chain," vol. 12, no. 4, pp. 332-342.

[6] Mohamed.M and Dalimin.M.N., "Sustainability : Linking Built and Natural Environment," Int. J. Integr. Eng. Spec. Issue ICONCEES, vol. 4, no. 3, pp. 1-8, 2012.

[7] Jabbour, A.B.L.S. \& Jabbour,C. J. C. (2009) "Are supplier selection criteria going green? Case studies of companies in Brazil," Industrial Management \& Data Systems, vol. 109, no. 4, pp. 477-495.

[8] Dubois,A. C. \& Pedersen,A. (2002) "Why relationships do not fit into purchasing portfolio models-a comparison between the portfolio and industrial network approaches," European Journal of Purchasing \&Supply Management, vol. 8, no. 1, pp. 35-42.

[9] Bennett, D. \& Klug, F. (2012) "Logistics supplier integration in the automotive industry," International Journal of Operations \& Production Management, vol. 32, no. 11, pp. 1281-1305.

[10] Simpson,D. F. \& Power,D. J.(2005) “Use the supply relationship to develop lean and green suppliers," Supply Chain Management: An International Journal, vol. 10, no. 1, pp. 60-68.

[11] Kumar Sahu,N. ,Datta,S. \& Sankar Mahapatra,S. (2014) “Green supplier appraisement in fuzzy environment," Benchmarking: An International Journal, vol. 21, no. 3, pp. 412-429.

[12] Lee,S.(2008) "Drivers for the participation of small and medium- sized suppliers in green supply chain initiatives," Supply Chain Management: An International Journal, vol. 13, no. 3, pp. 185-198.

[13] Genovese, A. ,Koh, S. C. L. , Bruno,G. \& Bruno,P. (2010) “Green Supplier Selection : a Literature Review and a Critical Perspective," Supply Chain Management and Information Systems (SCMIS), 2010 8th International Conference.

[14] Carr,A. S. , Kaynak, H., Hartley, J. L. \& Ross,A. (2008) “Supplier dependence: impact on supplier's participation and performance," International Journal of Operations \& Production Management, vol. 28, no. 9, pp. 899-916.

[15] Hwang,W. \& Min,H. (2013) “Assessing the impact of ERP on supplier performance," Industrial Management \& Data Systems, vol. 113, no. 7, pp. 1025-1047.

[16] Marksberry, P. (2012)“Investigating 'The Way' for Toyota suppliers," Benchmarking: An International Journal, vol. 19, no. 2, pp. 277-298.

[17] Rao,P. (2002) "Greening the supply chain: a new initiative in South East Asia," International Journal of Operations \& Production Management, vol. 22, no. 6, pp. 632-655.

[18] Zhu, Q.,Sarkis,J. \& Geng,Y. (2005) "Green supply chain management in China: pressures, practices and performance," International Journal of Operations \& Production Management, vol. 25, no. 5, pp. 449-468.

[19] Hatefi,S.M., "A multi objective model for supplier evaluation and selection in the presence of both cardinal and imprecise data," Int. J. Integr. Eng., vol. 9, no. 2, pp. 9-17, 2017.

[20] Lee,S. M., Tae Kim, S. \& Choi,D. (2012) “Green supply chain management and organizational performance,” Industrial Management \& Data Systems, vol. 112, no. 8, pp. 1148-1180.

[21] Hervani,A. a. , Helms,M. M. \& Sarkis, J.(2005) "Performance measurement for green supply chain management," Benchmarking: An International Journal, vol. 12, no. 4, pp. 330-353.

[22] Shaw, S. , Grant, D. B. \& Mangan,J. (2009) "Developing Environmental Supply Chain Performance Measures," Benchmarking: An International Journal. 
[23] Mingqiang,Z. \& Yabo,H. (2009) "The Application Proposal of Green Supply Chain Management in Construction Industry," 2009 Second International Conference on Intelligent Computation Technology and Automation, pp. 1006-1009.

[24] Zhu,Q. , Sarkis, J. \& Lai, K.(2007) "Green supply chain management: pressures, practices and performance within the Chinese automobile industry," Journal of Cleaner Production, vol. 15, no. 11-12, pp. 1041-1052.

[25] Testa F,I. F. (2010) "Shadows and Lights of GSCM (Green Supply Chain Management): Determinants and Effects of these Practices Based on a Multi-national Study," Journal of Cleaner Production, , vol. 18, pp. 953962. 